\title{
Asafoetida (Ferula asafoetida): A high-value crop suitable for the cold desert of Himachal Pradesh, India
}

\author{
Ruchi Sood \\ Chandigarh University, NH-95 Chandigarh-Ludhiana Highway, Sahibzada Ajit Singh \\ Nagar (Mohali) (Punjab), India \\ E mail: ruchi.e9872@cumail.in
}

\section{Article Info}

https://doi.org/10.31018/

jans.v12i4.2418

Received: October 26, 2020

Revised: December 2, 2020

Accepted: December 6, 2020

\section{How to Cite}

Sood R. (2020). Asafoetida (Ferula asafoetida): A high-value crop suitable for the cold desert of Himachal Pradesh, India. Journal of Applied and Natural Science, 12(4): 607 - 617. https://doi.org/10.31018/jans.v12i4.2418

\begin{abstract}
Asafoetida (Ferula asafoetida) also known as heeng, Devil's drug, ferula, food of Gods, incense of Devil, stinking gum is an important spice crop belonging to family Apiaceae. It is native to Iran and Afghanistan. Its dried latex (gum oleoresin) is generally used for flavouring curries, sauces, and pickles. Therapeutically, it stimulates the intestinal and respiratory tracts as well as the nervous system. It is beneficial in asthma, whooping cough, and chronic bronchitis. Its essential oil is also used in medicines, food and cosmetic industries. Besides, it is also used as an alternative for pesticides in organic farming. The major constituents of asafoetida are the resin (40$64 \%$ ), gum (25\%) and essential oil (10-17\%). The butyl propenyl disulphide is responsible for the aroma of asafoetida. The asaresinotannol is the major constituent present in the resin. It can be grown on unproductive cold deserts of dry temperate areas of Himalayas. It is mainly propagated by seeds. The seeds are sown either in winters or spring. It becomes ready for harvesting after 5 years of planting and yields around $900 \mathrm{~g}$ per plant. The oleo gum resin and essential oil derived from this plant are sold at premium prices in the international market. The small and marginal farmers of Kinnaur, Lahaul-Spiti and Chamba can benefit from this new emerging crop.
\end{abstract}

Keywords: Asafoetida, Apiaceae, Ferula asafoetida, Hing, Oleo gum resin

\section{INTRODUCTION}

Ferula asafoetida belongs to the family Apiaceae. It is known by various names like Asafoetida, Devil's drug, Ferula, Food of Gods, Incense of Devil, stinking gum, etc (Shah and Zare, 2014). In India, it is commonly known as Hing or Hingu. In different countries, it is known by other names as given in Table 1. It grows in cold arid regions of Afghanistan, Kazakhstan, Uzbekistan and Iran. The Gulmarg region of Kashmir in India also has small tracts of cultivation (Anonymous, 2020a).

It is oleo gum resin obtained from the stem and root of the plant. It is unpalatable in its purest form because of its pungent odour and stinking flavour. So, it is blended with flour and edible gum for consumption. The acrid taste and displeasing pungent odour is due to the presence of sulphur compounds. It contains about $40-$ $64 \%$ resin, $25 \%$ endogenous gum, $10-17 \%$ volatile oil and $1.5-10 \%$ ash (Takeoka, 2001). The sulphur compounds present in its resin had various biological activ- ities and therefore had great medicinal value. Ancient manuscripts consider it as a tempting spice with trusted medicinal properties. It is considered to be an anthelmintic, antiseptic, antispasmodic digestive, analgesic, carminative, diuretic, expectorant, laxative, and a sedative in its properties (Yaqoob and Nawchoo, 2016). In folklore and mythology, it is used to banish all negative energy, evil spirits and demons. In modern medicine, it is used to treat stomach cancer, asthma, bronchitis, dry cough, intestinal parasites, seizure, corns and calluses. It is also used to stop menstruation pain. It acts as a natural antidote for insect bites and stings (Mahendra and Bist, 2012). It is also used as a flavouring agent in Indian curries, dal, sambhar and pickles. It is used in developing green pesticides due to its antimicrobial and insecticidal properties (Salehi et al., 2019).

India consumes nearly $40 \%$ of the world's total production of asafoetida. The basic raw material is imported mainly from Iran and Afghanistan and processed into powder and tablet form for domestic and 
export markets. In 2015-16, India imported 1199 MT of asafoetida valued Rs 527.42 crores and after processing the raw material, exported around 885 MT valued Rs 46.27 crores (Hamid, 2019). The demand for quality asafoetida in the domestic, as well as in international markets, is high. The UK, Yemen, Belgium, Kenya, Malaysia, Oman, Switzerland, United Arab Emirates are the major importing countries. The price of quality asafoetida in the domestic market varies anywhere between Rs.10,000 to 15,000/- per kg (Anonymous, 2020a). The demand for this spice is rising at a steady rate because people in India have become health conscious.

While the product is finding increasing usage in India, asafoetida cannot be grown in most parts of India as the climate does not suit the plant. Since the cold deserts of Himachal Pradesh have the same climatic conditions that are found in Iran, Turkey and Afghanistan, therefore with refinement in cultural practices of asafoetida it can be made to grow in these regions. Its cultivation will uplift farmer's livelihood conditions in Kinnaur, Lahaul-Spiti and Bharmour of Chamba districts, as it is a high demand and profitable crop. Since the crop is newly introduced in our country, therefore cultivation under technical guidance would change the economy of hill states like Jammu \& Kashmir, Uttarakhand and Himachal Pradesh. One kg of pure asafoetida can fetch approximately Rs 35,000 to Rs 40,000 ( $\$ 469-s 536)$ in the international market. Hence, one hectare plantation is likely to increase farmer's income by seven times (Arya, 2020). Also the production of asafoetida in the country would reduce the dependence on other countries, thus saving valuable foreign exchange. In this review, efforts have been made to collect information on botanical description, origin and distribution, uses, chemical composition and cultivation practices of this valuable spice. Its harvesting and processing have also been reviewed.

Botanical description: The Latin name ferula means "carrier" or "vehicle". The Asa is a latinized form of Farsi asa "resin", and Latin foetidus means "smelling, fetid". Ferula is a monoecious, herbaceous and perennial plant. It belongs to the family Apiaceae or Umbelliferae. It grows to height of 2.5 to 3 meters with a circular mass of leaves having a diameter of 30$40 \mathrm{~cm}$. Flowering stems are $10 \mathrm{~cm}$ thick which are hollow inside with a number of schizogenous ducts in the cortex containing the resinous gum. It has large, compound, bipinnate, pubescent radical leaves with sheathing petioles. The inflorescence is also densely pubescent. Flowers are pale greenish-yellow in colour borne in large compound umbels. It has about 10-20 flowers in main umbels and 5-6 in the partial umbels (Peter, 2004; Mahendra and Bist, 2012).

There are two kinds of plants, male and female. The female plant produces inflorescences whereas the male plant does not. Only the female plant produces the oleo gum or asafoetida (Pruthi, 2001). Fruits are
Table 1. Common names of Ferula asafoetida in different countries.

\begin{tabular}{ll}
\hline Name of country & Common Name \\
\hline Afghanistan & Kama I anguza \\
Bangladesh & Hing \\
China & A-wei \\
England & Asafetida \\
Germany & Asafotida/Asant/Stinkasant/ \\
India & Teufelsdreck \\
Iran & Hengu/Hing/Ingu/Inguva/Kayam \\
Netherland & Zaz \\
Pakistan & Sagapeen \\
Russia & Anjadana/Kama I anguza \\
Srilanka & Asafetida \\
United states & Perunkayan \\
of America & Stinking Gum/Asafetida/Devil's \\
\hline
\end{tabular}

Source: Ross (2005)

oval, flat, thin, reddish-brown and have a milky juice. The fruits are $0.8 \mathrm{~cm}$ long and $0.6 \mathrm{~cm}$ broad, with tender hairs. The white exudate of the fruit is fragrant, pure and crystalline. The brownish to reddish exudate smells foul. The flowers and fruits generally appear in March-April. The shrub of Asafoetida needs 4 to 5 years for producing seed and after that plant dies. Carrot shaped roots are thick, massive, and pulpy which are covered with bristly fibres, with one or more forks. After about five years, the fusiform taproots attain a diameter of 12 to $15 \mathrm{~cm}$ at the crown which gives the indication that plant is ready for extraction of asafoeti$\mathrm{da}($ George, 2012). Roots yield a resin similar to that of the stems. All parts of the plant have a distinctive putrid smell (Ross, 2005; Peter, 2004; Shah and Zare, 2014). Tapping is usually done before flowering (March-April), when the plant sprouts from the taproot. After a month, the green foliage turns yellow. At this stage, the stem is cut near the crown. The milky juice exudes from the cut surface, which coagulates on exposure to air. After a few days, the exudate gum resin is scraped off (George, 2012; Giri et al., 2008).

Origin and distribution: The genus Ferula consists of about 130 species worldwide with the majority of thirty species found in Iran, of which fifteen are endemics (Mozaffarian, 1996; Mozaffarian, 1983). From India, only four species have been reported (Santapau and Henri, 1973). The species which yield 'Heeng' are $F$. assa-foetida Linn, $F$. narthex Boiss and $F$. alliacea Boiss. F. assa-foetida was native to Iran, Turkey and Afghanistan while $F$. narthex Boiss found wild in Afghanistan, Baltistan, Astore, Kashmir and Western Tibet. While $F$. alliacea Boiss originated from Iran and Afghanistan. From the Western Himalaya only one species, i.e., F. jaeschkeana Vatke. was reported by Rau (1975). The details of different species of asafoet- 
ida which originated in India and western Himalayas are given in Table 3.

According to Pandey (2008) there are two species which serve as source of asafoetida i.e, F. narthex or Hing Kabuli Sufaid (Milky white asafoetida) and $F$. foetida or Hing Lal (Red asafoetida). The plants of both species look almost identical. $F$. narthex, grows abundantly in Western Tibet and Afghanistan. In India, it was found in Kashmir and some parts of Punjab. Sultana et al. (2015) reported that $F$. asafoetida was grown chiefly in Afghanistan and Iran, and from these areas, it was exported to the entire world. According to Nadjafi et al. (2006), F. assa-foetida was widely spread in the steppes of Iran, Afghanistan, USSR, and West Pakistan and further from Zagros and Elburz mountains to Persian Gulf. While F. narthex was mainly found in Afghanistan, Russia (former USSR), West Pakistan, Baltistan,, Gilgit, Astore and also in Western Tibet. Dutt (1928) reported that $F$. alliacea Boiss grows in Eastern Persia, Khorasan and Kirman (Iran). It was mostly reddish in colour and popularly known as 'Multani Hing' which was used for cooking purposes.

Chemical composition: The food composition data showed that $100 \mathrm{~g}$ of asafoetida contains $68 \%$ carbohydrates, $16 \%$ moisture, $4 \%$ protein, $1 \%$ fat, $7 \% \mathrm{~min}$ - erals and $4 \%$ fibre. It also contains minerals and vitamins like calcium, phosphorus, iron, carotene, riboflavin and niacin (Gopalan et al., 1996; Takeoka, 2001). It is mainly rich in calcium (1.0 -1.5\%) and iron (5462mg/100g) (Pardeep et al., 1993).

It chiefly contains resin (40-65\%), gum (20-25\%), and volatile oil (4-20\%) (Iranshahy and Iranshahi, 2011; Handa and Kapoor, 1987). According to Pandey et al. (2008), it contains 50\% resin, $25 \%$ gum and $10 \%$ volatile oil. The resin fraction contains ferulic acid and its esters, coumarins, sesquiterpene coumarins and other terpenoids. Assaresinotannol is the chief sesquiterpene present in either free form or in a combined form with ferulic acid or galbanic acid (Wallis, 2004). The chemical constituents present in F. asafoetida, along with their pharmacological activities, are given in Table 2.

The gum includes glucose, galactose, 1-arabinose, rhamnose, glucuronic acid, polysaccharides and glycoproteins and the volatile fraction (Saeidy et al., 2018). The volatile fraction contain three sulphur compounds viz., 1-methylpropyl-1-propenyl disulphide, I(methylthio)-propyl-1-propenyl disulphide, and Imethyl-propyl 3-(methylthio)-2-propenyl disulphide. Same compounds had also been isolated from the

Table 2. Chemical constituents responsible for pharmacological activity Ferula asafoetida.

\begin{tabular}{|c|c|}
\hline Pharmacological activity & Chemical constituents \\
\hline Anticancer & $\begin{array}{l}\alpha-p i n e n e ; ~ \alpha \text {-terpineol; diallyldisulfide; ferulic-acid; isopimepinellin;luteolin; umbelliferone; } \\
\text { vanillin }\end{array}$ \\
\hline Anti-inflammatory & $\alpha$-pinene; azulene; $\beta$-pinene;ferulic-acid; isopimepinellin; luteolin;umbelliferone; \\
\hline Antileukemic & Luteolin \\
\hline Antimutagenic & Diallyl-sulifide; ferulic acid; luteolin; umbeliferone; vanillin \\
\hline Antineoplastic & Ferulic-acid \\
\hline Antitumor & Diallyl- disulfide; diallyl - sulifide; ferulic-acid; luteolin; vanillin \\
\hline Antiviral & a -pinene; diallyl- disulfide; ferulic acid; luteolin; vanillin \\
\hline Antibacterial & $\begin{array}{l}\text { a -pinene; } \alpha \text {-terpineol; azulene;diallyl - disulifide;diallyl - sulifide ferulic-acid; luteo- } \\
\text { lin;umbeliferone }\end{array}$ \\
\hline Antispasmodic & Azulene; ferulic-acid; luteolin; umbeliferone; valeric-acid \\
\hline Antiseptic & $\alpha$-terpineol; azulene; $\beta$-pinene; diallyl - sulifide; umbeliferone \\
\hline Antiulcer & Azulene \\
\hline Hepatoprotective & Ferulic-acid; luteolin \\
\hline Anti-HIV & Diallyl- disulfide; luteolin \\
\hline Antiinitrosaminic & Ferulic-acid; \\
\hline Antioxidant & Ferulic-acid; luteolin;vanillin \\
\hline Antitaggregant & Ferulic-acid; \\
\hline Tranquilizer & $\alpha$-pinene; valeric-acid \\
\hline Anticarcinogenic & Ferulic-acid; luteolin \\
\hline Sedative & a-pinene; alpha-terpineol; valeric-acid \\
\hline
\end{tabular}

Source: Mahendra and Bist (2012) 
Table 3. Different species of Asafoetida from India and Western Himalayas.

\begin{tabular}{ll}
\hline Sr No & Name of Species \\
\hline India & \\
1 & Ferula narthex (Falc.) Drude \\
2 & Ferula thomsoni \\
3 & Ferula jaeschkeana Vatke \\
Western Himalayas \\
1 & Ferula baluchistanica \\
2 & Ferula collina \\
3 & Ferula costata \\
4 & Ferula foetida \\
5 & Ferula heufellii \\
6 & Ferula hindukushensis \\
7 & Ferula jaeschkeana Vatke \\
8 & Ferula karelini \\
9 & F.kokanica Rgl. et Schmalh. \\
10 & Ferula lehmanni \\
11 & Ferula leucocarpum \\
12 & Ferula macrocolea \\
13 & Ferula microlobaBoiss. \\
14 & Ferula narthex (Falc.) Drude \\
15 & F.oopoda (Boiss. Et Buhse) Boiss. \\
16 & Ferula ovina Boiss. \\
17 & Ferula propinqua \\
18 & Ferula reppiae \\
19 & Ferula stewartiana \\
\hline
\end{tabular}

Source: Yaqoob and Nawchoo (2016)

resin. The latter two compounds had pesticidal properties (Takeoka, 2001). R-2-butyl-I-propenyl disulphide and 2-methyl-3-methylthio allyl disulphide were mainly responsible for the flavour of asafoetida.

The volatile oil contains terpenes, disulphide and pinene, which was mainly responsible for the therapeutic action of the species. The main constituent of the oil is isobutyl propenyl disulphide $\left(\mathrm{C}_{6} \mathrm{H}_{16} \mathrm{~S}_{2}\right)$. Bahrami et al. (2012) studied the chemical composition of the essential oil of the fruit of Ferula assa-foetida $L$. and identified 54 compounds. The major constituents of the oil were epi- $\alpha$-Cadinol $(23.15 \%)$, germacrene $\beta$ (10.98\%), a-gurjunene (6.18\%), (Z)-1-propenyl secbutyl disulfide (5.89\%), 5-epi-7-epi-a-eudesmol (4.89 $\%)$, $\delta$-cadinene $(4.78 \%), \gamma$-cadinene $(3.36 \%)$ and germacrene D $(3.09 \%)$ which constituted $96.9 \%$ of the total oil. Hadavand and Hasanloo (2014) reported thirty nine components in the essential oil of oleo gum resin of $F$. asafoetida obtained from Tabas and Yazd province of Iran. They found that E-1-propenyl secbutyl disulfide (40-44\%), Z-1-propenyl sec-butyl disulfide $(24-28 \%)$, Guaiol $(5.5-3.14 \%)$ and carotol (5.14$1.63 \%$ ) were the major components.

Moghaddam and Farhadi (2015) observed that (E)- propenyl sec butyl disulfide (37.30-53.99\%) and (Z)propenyl sec butyl disulfide $(12.10-23.10 \%)$ were the main constituents of the essential oil of $F$. asafoetida obtained from different rangelands in Kerman province of Iran. Hassanabadi et al. (2019) analysed fourteen accessions of asafoetida in which they discovered forty two components. In all the accessions, six compounds were largely available and these were $(E)-1$ propenyl sec-butyl disulfide (13.66-49.35\%), a-pinene (1.06-21.18\%), (Z)-1-propenyl sec-butyl disulfide (2.02 $-15.29 \%)$, a-pinene $(2.04-17.61 \%)$, thiophene $(0.03-$ $36.81 \%)$ and thiourea $(0.08-9.63 \%)$.

The essential oil content was directly and indirectly influenced by temperature, physical and chemical properties of soil and latitude, longitude and altitude, respectively. Karimi et al. (2020) identified chemotypes on the basis of essential oil obtained from the roots of ten Iranian accessions. The three chemotypes were attributed by mono terpenes and 2-1-propenyl sec butyl disulfide, eudesmane sesquiterpenoids and a agarofuran and $Z$ and E-1-propenyl sec butyl disulfide. The amount of oleo gum resin and its oil content was also significantly influenced by collection time. Karimian et al. (2020) obtained the highest amount of oleo gum resin (OGR) in September (13.2g) while lowest amount of OGR was obtained in July $(6.3 \mathrm{~g})$. The highest radical scavenging activity of OGR was observed in August. The total number of constituents present in OGR essential oil during July, August, September and October harvesting were 47, 47, 43 and 44, respectively. a-pinene, (Z)-propenyl-sec-butyl disulfide, $\beta$ pinene, bicyclogermacrene, (E)-propenyl-sec-butyl disulfide, germacrene $D$ and $(Z)-\beta$-ocimene were main constituents of OGR essential oil.

Kavoosi and Rowshan (2013) also observed that the harvesting dates of oleo gum resin also influence the chemical composition of their essential oils. The essential oil obtained from OGR harvested on 15th June, 2011 constituted high levels of cyclic sulfurcontaining compounds viz., (E)-1-propenyl sec-butyl disulfide and (Z)-1- propenyl sec butyl disulfide and bicyclic sesquiterpenes (10-epi-c-eudesmol). This essential oil also showed the highest radical scavenging and the lowest antibacterial and antifungal activities. While the essential oil obtained from OGR, harvested on 30th June also contained high levels of acyclic sulfur-containing compounds and bicyclic monoterpenes ( $\beta$-pinene and $\alpha$-pinene) but showed moderate radical scavenging, antibacterial and antifungal activities. On the other hand, the essential oil extracted from OGR obtained from third harvest (15th July) contain high levels of bicyclic monoterpenes ( $\beta$-pinene and $\alpha$ pinene) and heterocyclic disulfide (1, 2-dithiolane) and showed the lowest radical scavenging and the highest antibacterial and antifungal activities.

Traditional uses : Asafoetida has long been used in traditional medicine for the treatment of several diseases like epilepsy, paralysis, hysterias, depression, 
intestinal parasites, flatulence, weak digestion, stomach ache, influenza, asthma, premature labour, unusually painful, difficult and excessive menstruation, leucorrhoea, infertility and influenza etc. (Kavoosi and Rowshan, 2013). In India, dried extract of $F$. assafoetida with Brassica alba and rock salt was diluted with vinegar and taken orally as an abortifacient (Venkataraghavan and Sundaresan, 1981). For chronic bronchitis, the hot water extract of dried gum was taken orally. It was used to cure cholera when consumed along with cayenne pepper and sweet flag (Subrahmanyan et al., 1954). To avert the infection of guinea worm, the exudate of the dried gum resin was eaten (Joshi, 1991). It could be applied externally along with salt and the bark juice of Moringa pterygosperma for stomach aches (John, 1984). For curing the gallstones and kidney stones $200-300 \mathrm{~g}$ of asafoetida is mixed with Lampyris noctiluca without head and was consumed in morning and evening. For old stones, potassium nitrate was added to the mixture (Tiwari et al., 1979). The hot water extract of the dried resin is taken orally as an emmenagogue (Kamboj, 1988).

Nepali people also regularly consume it in their daily diets, and it was believed that asafoetida had aphrodisiac, sedative and diuretic properties. In Iranian folk medicine, asafoetida was also used as a medicine for the treatment of asthma. The most persistent uses of asafoetida was in upper respiratory diseases like asthma, bronchitis and whooping cough (Moghaddam et al., 2020). In addition, it had been used in traditional medicine of other countries such as Malaysia, Nepal and Fiji. In Iran, China and Nepal, it was traditionally used for the treatment of intestinal parasites (Iranshahy and Iranshahi, 2011; Gundamaraju, 2013). Oleo Gum resin of asafoetida had therapeutic effects on different diseases as documented in the Chinese, European, Iranian and Indian traditional medicinal books. Therapeutic effects related to the diseases of the nervous system, such as hysteresis and convulsion, were also available (Moghadam et al., 2014). It is used to decrease parasites like blastocystis species when taken either in powder form or oil form (El-Deeb et al., 2012). The extract of F. asafoetida and Silybum marianum reduce the symptoms of functional dyspepsia (Illuri et al., 2019). Asafoetida and turmeric in combination were used for the treatment of various inflammatory diseases like ulcerative colitis (Gopi et al., 2017). The F. asafoetida, Syzygium aromaticum and Carum carvi were used as potent molluscicides (Upadhyay et al., 2017). It was a promising natural therapeutic and prophylactic agent against cryptosporidiosis (Abdelmaksoud et al., 2020). Asafoetida mouthwash was recommended as an efficient herbal mouthwash for improving the indices of gingival health (Seyed Hashemi et al., 2019).

Modern uses: According to Sultana et al. (2015), asafoetida was proven for its various pharmacological and biological properties like antispasmodic, hypotensive, antinociceptive, antioxidant, anxiolytic, aphrodisiac, antiviral, antidiabetic, gastric, antiulcer, antiseptic, nephron protective, neuroprotective and anticancer in animals and humans. Mahendra and Bisht (2012) reported that it was the most important ingredient of digestive powders and the best remedy for flatulence. It should be dissolved in hot water and a pad of cloth steeped in it may be used for stimulating the stomach. It also had the ability to prevent the increasing incidences of cancer. As reported by Unnikrishn and Kuttan (1988) that the human lymphocytes activated when asafoetida was administered to humans at a concentration of $0.25 \mathrm{mg} / \mathrm{ml}$. The same authors in 1990 also reported that oral administration to mice increased the percentage of life span by $52.9 \%$. Nigam and Sachan (2013) also concluded that the occurrence of the cancer was more in those countries which had very low usage of asafoetida either as a spice or as medication.

With reference to women, asafoetida proved useful in the treatment of several problems such as sterility, unwanted abortion, pre-mature labour, unusually painful, difficult and excessive menstruation and leucorrhoea. It stimulates the secretion of progesterone hormone when about 12 centigrams of gum are fried in ghee along with 120 grams of goat's fresh milk and a tablespoon of honey. It is also useful for women after childbirth due to its antiflatulent and digestive properties (Mahendra and Bisht, 2012). Complete pregnancy inhibition was observed in Sprague-Dawley rats when methanol extract of the resin was given orally to these at a dose of $400 \mathrm{mg} / \mathrm{kg}$ daily for 10 days (Keshri et al., 1999).

It also possesses antihypertensive activity as evidenced by various studies. When water extract of the dried gum resin was administered intravenously to dogs at variable doses, it lowers their blood pressure (Sarkisyan, 1969). In another study tincture of the gland, administered intravenously to rabbits, produced significant hypotensive effects (Boyd, 1928). It showed anticoagulant activity when water extracts of the gum were given intravenously to dogs and rats at variable doses (Mansurov, 1967).

Several studies had shown that the extract, oleoresin powder, essential oil of asafoetida had antifungal activity (Garg et al., 1980; Dikshi and Husain, 1984; Soni et al., 1992; Thayagaraja and Hosono,1996). The volatile oils of the Pathani variety were effective antibacterial, whereas Irani varieties act as antifungal agents (Divya et al., 2014). The essential oils obtained from seed and oleo gum resin of $F$. asafoetida showed antimicrobial effects against oral pathogens (Alireza et al., 2019). It also induced hyperglycemia (Al-Awadi, 1985) and was highly effective in the treatment of Alzheimer disease (Shereen et al., 2013). It had cardioprotective effects in low doses and cardiotoxic effects in higher doses (Mansour Esmailidehaj et al., 2014). It had an- 
tiulcer and hepatoprotective activity (Bagheri et al., 2018). The minimum dose of $10 \mathrm{mg}$ per $100 \mathrm{~g} \mathrm{bw}$ gave maximum protection for colon cancer (Panwar et al., 2015). The oleo gum resin was found effective against Rhinovirus and influenza A H1N1 (Dissanayake and Perera, 2020).

During storage to improve the oxidative stability of fatty foods, the essential oil obtained from the earlier stages of $F$. assafoetida was used as safe and effective natural antioxidants. The essential oil obtained from the later stages of $F$. assafoetida was used in the health industry as an antimicrobial agent (Kavoosi and Rowshan, 2013; Golmohammadi, 2016).

In organic farming, it was used for the control of several insect-pests. It was used by farmers for the control of termites (Odontotemzes obesus). Its disagreeable odour repels termites and other insects (Meena et al., 2013). The leaf decoction of nirgundi $+10 \mathrm{~g}$ of Heeng mixed in 1 litre of water followed by mixing with 5 litres of cow urine control various pests of wheat and paddy (Lal and Verma, 2006). It was also found efficient in reducing the sucking pests (Noorani et al., 2016) in different crops.

Cultivars and varieties: Based on the relative flavour and quality there are various commercial varieties available. According to Peter (2004) the varieties are distinguished according to country of origin like Irani Hing from Iran and Pathani Hing from Afghanistan. The Irani and Pathani varieties have following properties:

Irani: In early stage, they appear dry, blackish brown or reddish brown or yellow in colour later they change their colour to deeper shades. The main varieties are Irani Ras, Irani Khada and Irani No. 1. They have sweet fetid odour, sweet taste and contain wood chips except in 'Irani Ras'. They contain $40 \%$ resin and $5-10 \%$ volatile oil and $0.5-7.75 \%$ ash.

Pathani: They are reddish to blackish brown or yellow or white in colour and appear agglutinated and wet. They have bitter fetid odour and bitter taste. They contain $10-20 \%$ volatile oil and $40-60 \%$ resin and only $0.7-1.90 \%$ ash. The major varieties are Naya Chal, Hadda, Naya Zamin, Charas, Galmin, Khawlal, Kabuli and Shabandi.

Climate and Soil: It requires dry temperate conditions for best growth. It can be grown at an elevation ranging from 600 to $2400 \mathrm{~m}$ above sea level. Heavy and continuous rainfall likely to affect crop growth adversely. It requires an annual average rainfall of 250-350 mm (Nadjafi et al., 2006). This plant grows on all aspects having a slope gradient of more than 25\% (Nadjafi et al., 2006; Jafari et al., 2019). The optimum temperature for its vegetative growth vary from $10-20^{\circ} \mathrm{C}$. However, it can tolerate temperatures up to $35^{\circ} \mathrm{C}$. The germination of Asafoetida is best at a temperature of $15^{\circ} \mathrm{C}$. It requires abundant sunshine and cannot tolerate shady conditions (Parsa et al., 2014; Zangoie et al., 2012). According to Moghad- dam and Farhadi (2015), the maximum accumulations of essential oil and sulphur compounds in asafoetida was associated with different mean annual temperatures and altitude. The contents of these parameters reduce with increasing altitude and decreasing temperature. However, the resin yield was positively correlated with the precipitation rate.

It prefers well-drained fertile sandy loam or clay soils (Ali, 2019). It can grow on poor soils with a light structure. It can tolerate $\mathrm{pH}$ ranging from acidic to basic soil types (Moghaddam and Farhadi, 2015). Jafari et al. (2019) observed that this plant grows well in soils where lime amount ranging from $55.92 \%$ to $58.27 \%$ and organic matter vary from $1.20 \%$ to $1.97 \%$.

\section{Cultivation}

Seed Sowing: The best method of propagating the plant is a seed. It begins to germinate within 20 days of sowing. Pirmoradi et al. (2013) reported that the elimination of the seed coat in one-year-old seeds lead to $84 \%$ germination within 4 days even at $20^{\circ} \mathrm{C}$ while newly harvested seed exhibit dormancy and did not germinate under any treatment condition. The germination was completed within a month.

In a greenhouse, the seeds should be sown as soon as they are ripe during the autumn season. The seedlings should be pricked out into individual pots as soon as they are large enough to handle. Under open conditions, winter or spring (April) sowings are preferred. The seed sown during winters, i.e. December-January gave higher emergence percentage and more tuber yield than spring plantings, i.e. April (Mellati et al., 2010; Varmazyar, 2013). During winters they should be given protective mulching. Varmazyar (2013) observed a higher emergence rate when seeds were sown $4 \mathrm{~cm}$ deep in rows as compared to sowing depth of $2 \mathrm{~cm}$. Sowings done in rows make it possible to rogue out weak off-type seedling from the field.

The seeds of asafoetida have long dormancy and poor seed germination (Golmohammadi, 2016). Therefore, to improve seed germination, cold stratification is done. The duration and temperature of stratification influence the seed germination. In general, at $4^{\circ} \mathrm{C}$ for 60 days was sufficient to remove the embryo dormancy (Zare et al., 2011). Otroshy et al. (2009) observed that when chilling treatment was given in combination with 6-benzylaminopurine (BAP), the germination percentage increases. For breaking dormancy of Tabas and Shirkooh populations of $F$. assafoetida on MS medium, seed treatment with chilling and cytokinins were most effective (Hassani et al., 2009). Also washing and chilling $\left(5^{\circ} \mathrm{C}\right)$ for a period of 14 days was found to be most effective (Nadjafi et al., 2006). Seed vernalization at $4-5^{\circ} \mathrm{C}$ for two weeks also increased seed germination by $50 \%$ (Nowruzian et al., 2017). In addition, washing seeds for 6 hours and applying $\mathrm{GA}_{3}$ @10 ml/l also augmented germination percentage. The right combination of vernalization, washing time 
and growth hormones was a prerequisite for proper germination of asafoetida.

According to Chittendon (1956), the vegetative propagation of the asafoetida plant can also be done by the root division method in the month of September. However, it was not an advisable method because plants dislike root disturbance.

Manures and fertilizers: In the first year, it was advised to apply $15-20$ t/ha of farmyard manure. The recommended dose of chemical fertilizers consists of $20 \mathrm{~g} \mathrm{~N}, 18 \mathrm{~g} \mathrm{P}_{2} \mathrm{O}_{5}$ and $25 \mathrm{~g} \mathrm{~K}_{2} \mathrm{O}$ per seedling. The dose was increased gradually up to ten years. Tenth year onward, a fertilizer dose of $200 \mathrm{~g} \mathrm{~N}, 180 \mathrm{~g} \mathrm{P}_{2} \mathrm{O}_{5}$ and $200 \mathrm{~g} \mathrm{~K}_{2} \mathrm{O}$ per plant was applied. In zinc deficient soils, basal application of zinc sulphate @ $30 \mathrm{~kg} / \mathrm{ha}$ should be applied for yield improvement. The intervention of earthing up should be followed after fertilizer application so that the fertilizer gets mixed in soil properly (Anonymous, 2020b).

Irrigation: Water stress reduces plant growth and productivity more than any other environmental factors (Tehri, 2016). The asafoetida prefers moist conditions only during germination. Waterlogging at later stages can be harmful. During summers, more number of irrigations were required (Anonymous, 2020b). According to Reza et al. (2015) irrigating the crop once in a week is sufficient. The resin yield, vegetative growth and \% survival of asafoetida plants also depends on the number of irrigations. Since the crop grows in high mountains, melting of snow in spring can meet the growth needs. However, if drought conditions persist, then watering the seedlings with sprinkler or drip should be done. The relative moisture of soil should be $40-75 \%$. Moghaddam and Farhadi (2015) also reported that resin yield was positively correlated with rainfall.

Interculture and weed control: During the early stages, asafoetida needs more care. Weeds which grow vigorously should be removed timely. Generally, two weedings in a year (June-July and OctoberNovember) and one digging of soil around the bushes during August-September were done (Anonymous, $2020 b$ ). After about four to five years, they do not need weeding.

Collection and harvesting: The crop grows into $2 \mathrm{~m}$ tall trees in five years' time and latex gum material was obtained from the roots and rhizomes of the plants. The older plants were more productive. The time to start harvesting the gum from the succulent stem and the root was just before flowering. March and April were the best months for harvesting the crop (Golmohammadi, 2016). The incision was made vertically on the stem near the roots of the plant. The roots which had attained 6-10 cm diameter were recommended for the extraction of asafoetida (Omid Beygi and Pirmoradei, 2006). A milky liquid oozes from the exposed surface. This substance hardens when exposed to air and later scraped and extracted. This process is repeated after every 4-5 days on the stems of asafoetida, till gum stops oozing (Shah and Zare, 2014; Giri et al., 2008, Ali, 2019).

Gholami and Mahdi (2015) evaluated the effects of different cutting methods (conventional method, crown cutting, concave and surface cutting) and the number of cuts (5, 10 and 13 times) on the yield of asafoetida in its natural habitat in Mazar area in Badzhestan district, Iran. The yield of gum was determined by the number of cuts. They reported that the highest yields and the best plant regeneration were achieved using the concave method with 10 cuts. They also revealed that the conventional method of cutting destroys the buds in the crown, which causes the death of the plant. Traditionally it was collected from wild pasture by using sickles to cut the entire plant or branches without considering natural regeneration which leads to the extinction of this valuable plant (Ali, 2019). Damanch and Sharafatmandrad (2017) also observed that the traditional incision methods were fatal to the asafoetida. They recommended that the 45-degree cutting method and concave method were the best incision techniques. The highest gum yield and best plant regeneration rates were obtained by using a concave method with 10 cutting times (Gholami and Faravani, 2014). Omid Beygi and Pirmoradei (2006) also found pruning up to tenth level economical. The entire process took three months to complete and one plant can yield up to $900 \mathrm{~g}$ of gum (Shah and Zare, 2014). The resinous gum appears greyish-white when fresh, and darkens to a deep yellow/amber when dried. Chunks of asafoetida resin are broken off to be sold commercially. The gum is seldom sold in its pure form. It is often combined with Arabic gum, wheat/rice flour, turmeric, etc. and sold as Compounded Asafoetida (Peter, 2004, Anonymous, 2017).

Yield: On an average, a single plant yields around $40 \mathrm{~g}$ to $900 \mathrm{~g}$ of fresh gum (Shah and Zare, 2014; Moghaddam and Farhadi, 2015) The value of $1 \mathrm{~kg}$ dried gum in the global market is around 130-170\$USD (Golmohammadi, 2014). The essential oil yield varies from 2.53 to $20.85 \%$. This high level of variation in yield occurs due to their place of cultivation (Hassanabadi et al., 2019). The oil extracted from different parts of asafoetida is also sold at premium prices.

Processing: According to Shah and Zare (2014), the oleo gum resin was extracted from the stem and roots of different Ferula species. When fresh, the resin is greyish-white, but after some days dries to a dark amber colour. Ali (2019) found that the dried sap of asafoetida was difficult to grate and traditionally, it was crushed between stones or using a hammer. Anonymous (2017) and Shah and Zare (2014) reported that in India, the purest form was natively known as hing which was usually soft, transparent, and obtained from stem of $F$. alliacea while hingra obtained from $F$. foeti$d a$, was exported. It was powdered when excessively cold or by drying over freshly burnt lime or exposure to 
Sood R. / J. Appl. \& Nat. Sci. 12(4): 607 - 617 (2020)

Table 4. Quality attributes of different types of Asafoetida available in the market.

\begin{tabular}{llll}
\hline Quality Attributes & Heeng & Heengra & Compounded Asafoetida \\
\hline Total ash max & 15.0 & 20.0 & 10.0 \\
Ash soluble in HCl \% (Maximum) & 2.50 & 8.00 & 1.50 \\
$\begin{array}{l}\text { Alcoholic extract \% (90\% alco- } \\
\text { hol) }\end{array}$ & 12 (Max.) & 50 (Max.) & 5 (Min.) \\
Starch \% & 1 & 1 & \\
\hline
\end{tabular}

Source: Shah and Zare (2014)

currents of warm air, and then it was reduced at low temperature. Starch or magnesium carbonate act as a diluent which maintains powdered form. According to Giri et al. (2008) the most commonly available form was compounded asafoetida, a fine powder containing $30 \%$ asafoetida resin, along with rice flour or maida (white wheat flour) and gum arabic. The compounded asafoetida was mostly sold in bricket form. It is also available in free-flowing (powder form) or in tablet forms. Different grades of resins, dried granules, chunks, or powders were sold. The quality attributes of different types of asafoetida available in the market are given in Table 4 .

Generally, it was marketed in three forms-tears, mass and paste. The most common form of asafoetida in the market is mass. Tears or lumps were the purest forms. They were round or flat, about 15-30 mm diameter and had greyish or dull yellow colour. In contrast, the mass was agglutinated tears mixed with extraneous matters. On the other hand, the paste was semi-solid and it also contains extraneous matter (Javaid et al., 2020).

Asafoetida was the most adulterated spice in the market. Besides being largely admixed with inferior qualities of asafoetida, it often had Gum Arabic, other gum resins, rosin, gypsum, red clay, chalk, barely, sand, stones, wheat flour, slices of potatoes etc. added to it to increase its weight (Peter, 2004; Ali, 2019; Javaid et al., 2020).

\section{Conclusion}

Asafoetida is mainly grown for the oleo gum resin which is extracted from its roots. It is valued for its medicinal properties against respiratory, gastrointestinal, neurological and reproductive disorders. In India, there is no tradition of cultivation of asafoetida, but recently it was introduced at village Kwaring, Lahaul valley, Himachal Pradesh, India by the team of scientists of Council of Scientific and Industrial Research-Institute of Himalayan Bioresource Technology. They were of the opinion that the cold desert areas of India are suitable for its cultivation. In addition, cultivation of this crop in farmland will be beneficial for the resourcepoor farmers of hill states. Thus, in view of the substantial economic importance of asafoetida, detailed studies on agrotechnology along with training and information sharing with the community, are required for its successful cultivation.

\section{Conflict of interests}

There is no conflict of interest regarding the publication of this article.

\section{REFERENCES}

1. Al-Awadi, F.M., Khattar, M.A. and Gumaa, K.A. (1985). On the mechanism of the hypoglycaemic effect of a plant extract. Diabetologia, 28 : 432-434. https://doi.org/10.10 07/BF00280886

2. Ali, Aziz (2019). On farm cultivation of economically important medicinal and aromatic plants for rural livelihood improvement in Chitral, Northern Pakistan. Examines Mar. Biol. Oceanogr., 2(5) : ABB.00549.2019. http:// doi:10.3 1031/EIMBO.2019.02.000549.

3. Alireza Daneshkazemi, Hengameh Zandi, Abdolrahim Davari, Mahmood Vakili, Majid Emtiazi, Reza Lotfi, and Seyed Mohammad Reza Masoumi. (2019). Antimicrobial activity of the essential oil obtained from the seed and oleo-gum-resin of Ferula assa-foetida against oral pathogens. Front Dent, 16(2) : 113-120. http://doi: 10.18502/fid.v16i2.1362.

4. Anonymous (2017). Compounded Asafoetida, Process Code No, CFTRI.res.in, Retrieved on November 152020 https://cftri.res.in/technologies/SFS/ compounded_asafoetida.pdf.

5. Anonymous (2020a). Hing with a home grown zing here is India's first batch of locally grown asafoetida. The Hindu, Retrieved on November 10 2020, https:// www.thehindu.com/life-and-style/food/indias-first-batch-ofhomegrown-asafoetida/article33064851.ece.

6. Anonymous (2020b). Asafoetida, Retrieved on November 152020 https://innovativeagriculture.in/horticulture/spices/ asafoetida/

7. Arya, N. (2020). Asafoetida cultivation: This state to cultivate hing worth Rs 40,000 per kg for the first time. Krishi Jagran, http://krishi jagran-com.cdn.ampproject.org/v/s/ krishijagran.com/agriculture-world.

8. Bagheri, S.M., Yadegari, M., Zare-Mohazabiye, F., Momeni-Asl, H., Mirjalili, A., Anvari, M. and Behpour, M. (2018). Effect of Ferula assa foetida oleo-gum resin on gastric ulcer in indomethacin-ulcerated rats. J Curr. Res. Sci.Med., 4:42-46. http://doi: www.jcrsmed.org/text.as p/2018/4/1/42/233196.

9. Bahrami, G., Soltani, R., Sajjadi, S.E., Kanai, M.R. Naderi, R., Ghiasvand, N. and Shokoohinia, Y. (2012). Essential oil composition of Ferula assa-foetida L. fruits from Western Iran. Journal of Reports in Pharmaceutical Sciences, 1(1): 7-18.

10.Barat Ali Gholami and Faravani Mahdi. (2014). Influences of different cutting methods and number of cuts on the growth and production of rubber of the plant Ferula assa- 
foetida. Journal of Agricultural Sciences, 59( 1): 35-44.

11.Boyd, L.J. (1928). The pharmacology of the homeopathic drugs. I. J. Am. Inst. Homeopathy, 21(7):

12.Chittendon, F. (1956). RHS Dictionary of Plants plus Supplement. Oxford University Press. UK.

13.Damanch, N.E. and Sharafatmandrad, M. (2017). Assessing the effects of different incision techniques on Ferula asafoetida properties. Journal of Rangeland Science, 7 (1) : 45-53.

14.Dikshit, A. and Husain, A. (1984). Antifungal action of some essential oils against animal pathogens. Fitoterapia, $55: 171-176$.

15.Dissanayake, K.G.C. and Perera, W.P.R.T. (2020). Medicinal importance of Ferula asafoetida oligo gum resin against infective diseases. Journal of Medicinal Plants Studies, 8(2): 135-139.

16.Divya, K., Ramalakshmi, K., Murthy, P.S. and Mohan Rao, L.J. (2014). Volatile oils from Ferula asafoetida varieties and their microbial activity. LWT- Food Science and Technology, 59(2) : 774-779. http://doi:10.1016/ j.Iwt.2014.07.013.

17.Dutt, N.B. (1928). Commercial Drugs of India. Thacker, Spink \& Co., Calcutta and Simla.

18.El-Deeb, H.K., Khadrawy, F.M., Abd El-Hameid, A.K. (2012). Inhibitory effect of Ferula asafoetida L. (Umbelliferae) on Blastocystis sp. subtype 3 growth in vitro. Parasitol. Res., 111 : 1213-1221.

19.Garg, D.K., Banerjea, A.C. and Verma, J. (1980). The role of intestinal Clostridia and the effect of asafoetida (Hing) and alcohol in flatulence. Indian J Microbiol. 20 : 194-197.

20.George, C.K. (2012). Asafetida. Handbook of Herbs and Spices, $2^{\text {nd }}$ Ed. Volume 2. https:// doi.org/10.1533/9780857095688.151

21.Gholami, B.A. and Faravani, M. (2014). Effects of different cutting methods and times of cutting on growth performance and gum resin production of Ferula assafoetida. Journal of Agricultural Sciences, 59(1) : 35-44. http:// doi:10.2298/JAS1401035G.

22.Giri, S.K., Prasad, N., Pandey, S.K., Prasad, M and Babloo, B. (2008). Natural Resins and gums of commercial importance- At a glance. Technical Bulletin, Indian Institute of Natural Resins and Gums, ICAR, pp 35-36.

23.Golmohammadi, Faehood (2016). Ferula assa-foetida as a main medicinal plant in East of Iran (Harvesting, main characteristics and economical importance). Journal of Progressive Agriculture, 7(2) : 1-15.

24.Gopalan, C., Rama Sastri B.V., Balasubramanian, S.C., Rao Narasinga B.S., Deosthale Y.G. and Pant K.C., (1996). Nutritive Value of Indian Foods. Pub. National Institute of Nutrition, (I.C.M.R.), Hyderabad pp 1-156.

25.Gopi, S., Amalraj, A., Jude, S., Varma, K., Sreeraj, T.R., Haponiul, Jozef T. and Thomas, S. (2017). Preparation, characterization and anticolitis activity of curcumin asafoetida complex encapsulated in turmeric nanofiber. Mater Sci. Eng. C. Mater Biol. Appl., 81(1):20-31. http:// doi:10.1016/j.msec.2017.07.037.

26. Gundamaraju, R. (2013). Evaluation of anti-helmintic activity of Ferula foetida "Hing- A natural Indian Spice" aqueous extract. Asian Pac. J. Trop. Dis., 3:189-191.

27.Hadavand, M.H. and Hasanloo, T. (2014). Assessment of chemical composition of essential oil of $F$. assa-foetida oleo gum resin from two different sites of Yazd province in the center of Iran. Research J. Pharmacognosy, 1(2):5154.

28.Hamid, N. (2019). Heeng cultivation: Untrapped agripre- neurship opportunity in J\&K. Greater Kashmir, January 8, 2019 Retrieved on September 29, 2020 from https:// www.greaterkashmir.com/news/opinion.

29.Handa, S.S. and Kapoor, V.K. (1987). Pharmacognosy. Vallabh Prakashan, New Delhi, pp 52.

30. Hassanabadi, M., Mohsen Ebrahimi, Mostafa, F. and Ata, D. (2019). Variation in essential oil components among Iranian Ferula assafoetida L. accessions. Industrial Crops and Products, 140. http://doi.org/10.1016/j.indcrop.20 19.111598.

31.Hassani, B., Saboora, A., Radjabian, T., and Fallah Husseini, H. (2009). Effects of temperature, $\mathrm{GA}_{3}$ and Cytokinins on breaking seed dormancy of Ferula assa-foetida L. Iranian Journal of Science and Technology (Sciences), 33 (1): , 75-85.

32.Illuri, R., Venkataramana, S.H., Daguet, D. and Kodimule, S. (2019). Sub acute and acute toxicity of Ferula asafoetida and Silybum marianum formulation and effect of the formation on delaying gastric emptying. BMC complementary and Alternative Medicine, 19(1):159. http:// doi:10.1186/s12906-019-2576-7.

33.Iranshahy, M. and Iranshahi, M. (2011). Traditional uses, phytochemistry and pharmacology of asafoetida (Ferula assafoetida oleo-gum-resin)-A review, Journal of Ethnopharmacology, 134(1): 1-10.

34.Jafari, S.H., Sepehry, Adel., Soltanloo, H. and Karimian, A.A. (2019). Effect of topography and soil properties on distribution of Ferula pseudalliacea (Bitter Asafoetida) in Yazd Province. Iran Journal of Rangeland Science, 9(2): 184-195.

35.Javaid, R., Javed, G., Javaid, R., Anju, Ahmed, F and Khan, A.A. (2020). Hing (Ferula foetida Regel.): A potent Unani herb with its descriptive parameters of pharmacognosy and pharmacology: A review. Journal of Drug Delivery and Therapeutics, 10 (5):362-367. http:// dx.doi.org/10.22270/jddt.v10i5.4372.

36.John, D. (1984). One hundred useful raw drugs of the Kani tribes of Trivandrum forest division, Kerala, India. Int. J. Crude Drug Res., 22 : 17-89.

37.Joshi, P. (1991). Herbal drugs used in Guinea worm disease by the tribals of southern Rajasthan (India). Int. J. Pharmacog., 29: 33-38.

38.Kamboj, V.P. (1988). A review of Indian medicinal plants with interceptive activity. Indian J. Med. Res., 3: 336-355

39.Karimi, A., Andrea Krahmer, Herwig, N., Hadian, J and Torsten, S. H. (2020). Metabolomics approaches for analyzing effects of geographic and environmental factors on the variation of root essential oils of $F$. assa-foetida. Journal of Agricultural and Food Chemistry, 68(37) : 99409952. http://doi.org/10.1021/acs.jafc.Oc03681.

40.Karimian, V., Sepehry, A., Barani, H., Ebrahimi, S.W. and Mirjalili, M.H. (2020). Productivity, essential oil variability and antioxidant activity of Ferula assa-foetida L.oleo gum resin during the plant exploitation period. Journal of Essential Oil Research, 32(6): 545-555. http:// doi.org/10.1080/10412905.2020.1794988.

41.Kavoosi, G. and Rowshan, V. (2013). Chemical composition, antioxidant and antimicrobial activities of essential oil obtained from Ferula assa-foetida oleo-gum resin: Effect of collection time. Food Chemistry, 138: 2180-2187.

42.Keshri, G., Lakshmi, V., Singh, M.M. and Kamboj, V.P. (1999). Post coital antifertility activity of Ferula assafoetida extract in female rats. Pharm. Biol., 37: 273-276.

43.Lal, Chaman and Verma, L.R. (2006). Use of certain bioproducts for insect-pest control. Indian Journal of Tradi- 
tional Knowledge, 5(1); 79-82.

44.Mahendra, P and Bist, S. (2012). Ferula asafoetida: Traditional uses and pharmacological activity. Pharmacognosy Reviews, 6(12): 141-6. https://doi: 10.4103/09737847.99948

45.Mansour Esmailidehaj, Mohadeseh Kakoo, Mohammad Ebrahim Rezvani, and Mohammad Hossein Mosaddeghmehrjardi. (2014). Pretreatment with Assafoetida exerts dose-dependent dual effects on rat hearts. Pharmacogn Mag., 10(38): 147-153.

46.Mansurov, M.M. (1967). Effect of Ferula asafoetida on the blood coagulability. Meditsinskii Zhurnaluzbekistana, 6:4649.

47.Meena, R.K. Singh, Y.V., Bana, R.S.,Nath, C.P. and Kaur, R. (2013). Pests and diseasemanagement in organic crop production systems. Popular Kheti, 1(4) : 164-170.

48.Mellati, F., Parsa, M., and Lalehgani, B. (2011). Evaluation of Germination Behaviour and Sowing Date in Dorema, Asafetida and Galbanum. Iranian Journal of Field Crops Research, 8(3): 521-530. https://doi.org/10.22067/ gsc.v8i3.7771

49.Moghadam, F.M., Dehghan, M., Zarepur, E., Dehlavi, R., Ghaseminia, F., Ehsani, S., Mohammadzadeh, G. and Barzegar, K. (2014). Oleo gum resin of Ferula assafoetida L. ameliorates peripheral neuropathy in mice. Journal of Ethnopharmacology, 154 (1) : 183-189. http:// doi.org/10.1016/j.jep.2014.03.069.

50._Moghaddam, M. and Farhadi. N. (2015). Influence of environmental and genetic factors on resin yield, essential oil content and chemical composition of Ferula assafoetida L. populations. Journal of Applied Research on Medicinal and Aromatic Plants, 2(3): 69-76. https:// doi.org/10.1016/j.jarmap.2015.04.001.

51.Moghaddam, S.G.M., Kianmehr, M. and Khazdair, M.R. (2020). The possible therapeutic effects of some medicinal plants for chronic cough in children. Evid based complement Alternat. Med., http://doi:10.1155/2020/21493 28.ecollection2020.

52.Mozaffarian, V. (1983). The family of umbelliferae-Iran key and distribution. Research Institute of Forests and Rangelands Press, Tehran, pp 114-116.

53.Mozaffarian, V. (1996). A Dictionary of Iranian Plant Names, Farhang-e Moaser, Tehran.

54.Nadjafi, Farsad., Bannayan, Mohammad., Tabrizi, Leila and Rastgoo, Mehdi. (2006). Seed germination and dormancy breaking techniques for Ferula gummosa and Teucrium polium. Journal of Arid Environments, 64: 542-547. http://doi :10.1016/j.jaridenv.2005.06.009

55.Nigam, U. and Sachan, S. (2013). Evaluation of Ferula assafoetida for its anticancer activity in different countries. J. Pharmacogn. Phytochem., 2 (4):74-76.

56.Noorani, A.M., Abro, G.H., Khuhro, R.D. and Buriro, A.S. (2016). Efficacy of bio pesticides for management of sucking insect pests of cotton: Gossypium hirsutum (L.). Journal of Basic and Applied Sciences, 12: 306-313.

57.Nowruzian A, Masoumian M, Ebrahimi M A, Bakhshi khaniki G R. (2017). Effect of Breaking Dormancy Treatments on Germination of Ferula assa-foetida Seed. Iranian J. Seed Res., 3 (2) :155-169. URL: http://yujs.yu.ac.ir/ jisr/article-1-215-en.html.

58.Omid Beygi, R. and Pirmoradei, M.R. (2006). A study of the effect of root diameter and incision time on gum yield in medicinal rangeland asafoetida (Ferula asafoetida L.) plant. Iranian Journal of Natural Resources, 59(1):261-
269.

59.Otroshy, M., Zamani, A., Khodambashi, M., Ebrahimi, M., and Struik, P.C. (2009). Effect of exogenous hormones and chilling on dormancy breaking of seeds of Asafoetida (Ferula assa - foetida L.). Research Journal of Seed Science, 2(1) : 9-15.

60.Pandey, Ajai. (2008). A Hand Book of Ayurveda. http:// doi:10.13140/2.1.4940.3845.

61.Panwar, R., Rana, S., Dhawan, D.K. and Prasad, K.K. (2015). Chemopreventive efficacy of Ferula asafoetida oleo gum resin against 1,2-dimethylhydrazine $(\mathrm{DMH})$ induced rat colon carcinogenesis. The Journal of Phytopharmacology, 4(6) :282-286. http:// dx.doi.org/10.31254/ phyto.

62.Pardeep, K.U.,Geervani, P. and Eggum, B.O. (1993). Common Indian Spices: nutrient composition,consumption and contribution to dietary value. Plant food for human nutrition, 44(2) : 137-148.

63.Parsa, S., Mahmoodi, S., Al-Alahmadi, M.J. and Sanjari, G. (2014). Effect of temperature regimes on seed germination of asafoetida (Ferula assa-foetida L.). Plant Breeding and Seed Science, 69(1):59-68. http://doi:10.1515/ plass-2015-0006.

64.Peter, K.V. (2004). Handbook of herbs and spices. Vol 2. CRC Press, Boca Raton, USA.

65.Pirmoradi, M.R., Omid Beygi, R. Naghavi, M.R., Baghizadeh, A. and Yadollahi, Abba. (2013). Effect of elevation and different treatments on asafoetida (Ferula assafoetida L.) seed germination. J. Iran. Crop. Sci.43:463471. (In Farsi)

66.Pruthi, J.S. (1976). Spices and condiments. National Book Trust, India, New Delhi. pp 1-269.

67.Rau, M.A., (1975). High altitude flowering plants of West Himalaya. Botanical Survey of India, Howrah-1.

68.Reza, P.M., Moghaddam Mohammad and Yazdani, N. (2015). The effect of different irrigation treatments on resin yield, essential oil content, morphological traits and survival of better asafoetida (Ferula asafoetida L.). Journal of Rangeland and watershed management (Iranian J. Natural Resources), 68(1) : 25-34.

69.Ross, I.A. (2005). Ferula assafoetida. In: Medicinal Plants of the World, Volume 3. Humana Press. https:// doi.org/10.1007/978-1-59259-887-8_6.

70.Saeidy, S., Nasirpour, A., Keramat, J., Desbrieres, J. and Gillaume, D.L. (2018). Structural characterization and thermal behaviour of a gum extracted from $F$. asafoetida L. Carbohydrate Polymers, 181: 426-432.

71.Salehi, M., Naghavi, M.R. and Bahmankar, M. (2019). A review of Ferula species: Biochemical characteristics pharmaceutical and industrial applications and suggestions for biotechnologists. Industrial Crops and Products, 139:111511. http://doi.org/10.1016/j.indcrop.2019.111511.

72.Santapau, H. and Henry, A.N. (1973). A Dictionary of the flowering Plants in India, CSIR, New-Delhi. 198 pp.

73.Sarkisyan, R.G. (1969). Effect of Ferula on arterial pressure. Meditsinskii Zhurnal Uzbekistana: 23-24.

74.Seyed Hashemi, M., Lofti, M.H., Hemat, H., Mousavi, Z., Emtiazy, M. and Vaziri, F. (2019). The efficacy of asafoetida (Ferula assa-foetida oleo-gum resin) versus chlorhexidine gluconate mouthwash on dental plaque and gingivitis: A randomized double blind controlled trial. European Journal of Integrative Medicine, 29:1876-3820. http:// doi:org/10.1016/j.eujim.2019.100929.

75.Shah, N.C. and Zare, Amir (2014). Asafoetida (Heeng): The well known medicinal-condiment of India and Iran. 
The Scitech Journal, 1(3): 30-36.

76.Shereen, K. Ali., Ahmed, R. H.amed, Maha, M. S.oltan, Usama, M. Hegazy, Esameldin, E. El.,gorashi, Ibrahim, A. El-Garf, and Ahmed, A. Hussein. (2013). In-vitro evaluation of selected Egyptian traditional herbal medicines for treatment of alzheimer disease. BMC Complement Altern Med., 13:121.

77.Soni, K.B., Rajan, A. and Kuttan, R. (1992). Reversal of aflatoxin induced liver damage by turmeric and curcumin. Cancer Lett., 66:115-21.

78.Sultana, Asma K., Khaleequr Rahman, Rahman Shafeequr (2015).Oleo-gum-resin of Ferula asafoetida: A traditional culinary spice with versatile pharmacological activities. Res. J. Recent Sci., 4:, Issue (IVC-2015), 6-22.

79.Takeoka, G. (2001). Volatile constituents of Asafoetida. In: Takeoka G.R., Guntert, M., Engel K.H., eds. Aroma Active Compounds in Foods,. American Chemical Society, Washington DC: American Chemical Society, pp 33- 44.

80.Tehri, G.H. (2016). Effect of chitosan spraying on physiological characteristics of Ferula flabelliloba (Apiaceae) under drought stress. Iranian J. Field Crops Research, 13 (4):728-737.

81. Thayagaraja, N. and Hosono, A. (1996). Effect of spice extract on fungal inhibition. Food Sci Technol., (London), 29: 286-8.

82.Tiwari, K.C., Majumder, R. and Bhattacharjee, S. (1979). Folklore medicines from Assam and Arunachal Pradesh (district Tirap). Int. J. Crude Drug Res., 17:61-67.

83.Unnikrishnan, M.C. and Kuttan, R. (1988). Cytotoxicity of extracts of spices to cultured cells. Nutr Cancer, $11: 251-7$.

84.Unnikrishnan, M.C. and Kuttan, R. (1990). Tumour reduc- ing and anti-carcinogenic activity of selected spices. Cancer Lett., 51 :85-9.

85.Upadhyay, P.K., Singh, S. Agarwal, G. and Vishwakarma, V.K. (2017). Pharmacological activities and therapeutic uses of resins obtained from Ferula asafoetida Linn.: A review. International Journal of Green Pharmacy, 11(2) : 240-247.

86.Varmazyar, Fatemeh., Melati, Feraidon., Kamalodin, Naseri and Mehdi, Rastgoo. (2013). Effect of sowing dates and depths on emergence characteristics and tuber production of medico-industrial Ferula assa-foetida. 2nd National Congress on Medicinal Plants, 15-16 May, 2013, Tehran, Iran.

87.Venkataraghavan, S. and Sundaresan, T.P. (1981). A short note on contraceptives in Ayurveda. J. Sci. Res. PI. Med., 2 : 39.

88.Wallis, T.E. (2004). Textbook of Pharmacognosy 5th Ed. CBS Publisher, New York, pp 503-5.

89.Yaqoob, Ubaid and Nawchoo, Irshad Ahmad. (2016). Distribution and Taxonomy of Ferula L: A Review. Research \& Reviews: Journal of Botany, 5(3) :15-23.

90.Zangoie, M., Parsa, S., Mahmoodi, S., Jamialahmaddi, M. (2012). Evaluation of cardinal temperature for germination of Asafoetida (Ferula assafoetida L.) seed. Journal of Plant Production (Journal of Agricultural Sciences and Natural Resources), 19(3) :193-202.

91.Zare, A.R., Solouki, M., Omidi, M., Irvani, N., Abbasabadi, A.O. and Nezad, N.M. (2011). Effect of various treatments on seed germination and dormancy breaking in Ferula assafoetida a threatened medicinal herb. Trakia Journal of Sciences, 9(2) : 57-61. 